\title{
When "Ottumwa Went to the Dogs": The Erosion of Morrell-Ottumwa's Militant Unionism, 1954-1973
}

\author{
WILSON J. WARREN
}

BEGINNING IN THE 1930s, workers' struggles for power at the John Morrell and Company meatpacking plant in Ottumwa, Iowa, created a militant brand of industrial unionism. Morrell workers established United Packinghouse Workers of America (UPWA) Local No. 1, a strong CIO union built on the bonds of a homogeneous packing community, anger at Morrell's unjust labor relations, and workers' desire to exercise more control in the plant as well as in the community. By the end of World War II, workers had not only won contractual and informal concessions of power from Morrell, they had also established a powerful political presence in the larger community. Soon after the war, however, Morrell and the local business community reasserted themselves against Local No. 1 . The struggle for power in plant and community affairs peaked between the nationwide UPWA meatpacking strike of 1948 and the declaration of "Morrell Days" by the company in 1954.

During those immediate post-World War II years, Local No. 1 and Morrell battled for control over plant floor decisions.

An early draft of this paper was presented at the 1994 lowa Heritage Expo. I thank John Schacht and other participants at the conference for their comments. I am again grateful to Mark Smith, secretary-treasurer of the Iowa Federation of Labor, AFL-CIO, for allowing me access to and permission to cite interviews in the Iowa Labor History Oral Project (ILHOP) held by the State Historical Society of Iowa, lowa City, Iowa. I would also like to thank Bruce Fehn, Marvin Bergman, and anonymous readers for The Annals of Iowa for their substantive and editorial suggestions.

THE ANNALS OF IOWA 54 (Summer 1995). CThe State Historical Society of Iowa, 1995. 
From the mid-1940s to early 1950s, Morrell officials had reasserted their prerogatives over production decisions through the creation of an industrial engineering department and the appointment of supervisors willing to challenge the union's power. In December 1953 Morrell's board of directors selected a new president, W. W. McCallum, the first non-Morrell family member to be president in the company's 126-year history. McCallum was bent not only on wresting power away from Local No. 1 but also on implementing strategies that would shift production away from the Ottumwa plant. McCallum's financial and production strategies, combined with changes prompted by the transformation of the meatpacking industry in the 1950 s and 1960s, undermined Local No. 1's militancy.

Internal disputes within Local No. 1 were just as important in the erosion of the union's militancy during the 1950s and 1960s. Discord started during and immediately following World War II, when Morrell hired many rural workers to meet its expanded labor needs. These and other workers who started working at the plant following World War II were largely unsympathetic to the sentiments underlying Local No. 1's militancy. Largely unaccustomed to unionism and not part of the packing community traditions of the local's founders, they subverted the union's efforts to block changes in work rules dictated by the company in the late 1940 s and early 1950s. The union would undergo further fragmentation during the 1960s, when women workers, whose concerns had long been ignored by the local's male leadership, battled for job equality in the plant. The erosion of Local No. 1's militancy left it virtually powerless when Morrell prepared to close its Ottumwa plant in the early 1970s. As one longtime Morrell worker put it, these were the years when "Ottumwa went to the dogs."

MORRELL WORKERS in Ottumwa received the first CIO packinghouse union charter in the United States in May 1937. In 1943 , in recognition of that status, the CIO designated their local as UPWA Local No. 1, a designation members would point

1. Ray L. Cavin, interview with author, 1982 Morrell Survey, collection-in author's possession. 
to proudly in years to come. The local emerged out of a closeknit and culturally uniform neighborhood in the immediate environs of the Morrell plant in Ottumwa's east end. As early as 1900, 60 percent of Morrell's workers were native-born of native parents. By the mid-1930s, over 95 percent of Morrell's workers were native-born of northern and western European stock. Many attended fundamentalist Protestant churches and belonged to the Eagles, Moose, and American Legion halls situated in the city's blue-collar residential areas, including the east end. ${ }^{2}$

Between 1938 and the end of World War II, Ottumwa's Morrell workers were able to secure favorable informal production rules in key departments of the plant. One of the most important of those agreements concerned the number of cattle killed per hour by the floorsmen. Beginning in the late 1930s, after confrontations stemming from sit-down strikes, the beef department superintendents and foremen agreed to abide by limits proposed by workers in the department. Job load issues were largely resolved this way in many departments throughout the plant at the same time. As a result, the union exercised considerable power. In 1942, however, Morrell established a counteroffensive. The company introduced a new industrial engineering department that took production decisions away from departmental supervisors who had previously negotiated informal production rules with the local union. In 1947 Morrell also hired a new plant superintendent, Charles L. Campbell, who directly confronted the union over production-related issues through $1952 .^{3}$

2. For more information on Ottumwa's workers' social and cultural identification, see Wilson J. Warren, "The Limits of New Deal Social Democracy: Structural Pluralism in Midwestern Meatpacking, 1900-1955" (Ph.D. diss., University of Pittsburgh, 1992), 131-32, 319-20, 330, 604; and idem, "The Heyday of the CIO in Iowa: Ottumwa's Meatpacking Workers, 1937-1954," Annals of Iowa 51 (1992), 365-67.

3. On the history of union-management conflict in Morrell's Ottumwa plant between 1937 and 1954, see Warren, "The Heyday of the CIO in Iowa," 363-89. For a more detailed account of this conflict, see Warren, "The Limits of New Deal Social Democracy," 295-351, 516-70. For detailed accounts of the establishment of the beef department job load and other informal production rules, see Virgil Bankson, interview with author, 26 September 1982; and interview 
During that six-year period, Campbell and the industrial engineering department initiated many changes in work rules, most of which increased job loads. For example, beginning in 1949, Morrell demanded that Ottumwa's beef kill department slauginter twice as many cattle per hour as the company's Sioux Falls plant did with the same number of men. Union officials in Ottumwa complained that Morrell unfairly targeted Ottumwa's CIO work force while avoiding antagonizing Sioux Falls's more cooperative Amalgamated Meat Cutters and Butcher Workmen (AMCBW-AFL) work force. In this case, Campbell told the Ottumwa local that if they did not like the job load situation, then "why don't you strike?" Throughout this period, the local used wildcat strikes to combat the changes in work rules. The battles reached a peak in 1951, when there were eighty-eight separate walkouts at the Ottumwa plant. ${ }^{4}$

On the heels of these repeated and massive walkouts, UPWA District No. 3 Director Russell Bull, at the urging of

with Paul Kelso, 1978, Iowa Labor History Project (ILHOP), State Historical Society of Iowa (SHSI), Iowa City; Art Bankson, interview with author, 17 May 1983; Paul Bissell, interviews with author, 10 January 1983 and 25 November 1984; Dorothy Daeges, interview with author, 9 September 1982; George Gail, interview with author, 13 January 1983; Donald Jones, interview with Leslie Orear, 14 January 1974, Local P-1 Records, Amalgamated Meat Cutters and Butcher Workmen of North America (AMCBW-NA, AFL-CIO), SHSI; and Donald Jones, interview, 20 October 1978, ILHOP. Although workers expressed their desire for more control in other respects as well, their militant solidarity is akin to the "mood of syndicalism" that Bruce Nelson describes among Pacific Coast waterfront workers in Workers on the Waterfront: Seamen, Longshoremen, and Unionism in the 1930s (Urbana, IL, 1988).

4. The 1949 job load controversy is described in The Bulletin, 14 April, 2 and 16 May, 6 and 20 June, 13, 18, and 25 July, 15 August, and 19 September 1949, folder 7, box 411, UPWA Records, State Historical Society of Wisconsin (SHSW), Madison, Wisconsin; John Morrell and Co. Executive Department Announcement, 16 April 1949, ibid.; Edward Filliman, UPWA field representative, weekly reports, 30 April, 7 and 21 May, 11, 18, and 25 June, 2 and 30 July, 6 August, 10 September, 22 October, 5, 12, and 26 November 1949, ibid.; Russell Bull, UPWA District 3 assistant director, to Ralph Helstein, UPWA president, 9 May and 16 June 1949, folder 5, ibid.; and National Provisioner, 17 December 1949. See also Warren, "The Limits of New Deal Social Democracy," 554-55; and idem, "The Heyday of the CIO in Iowa," 384-86. For a discussion of the national context of wildcat strikes and walkouts during the late 1940s, see George Lipsitz, Rainbow at Midnight: Labor and Culture in the 1940s (Urbana, IL, 1994), 229-52. 
some segments of Local No. 1's membership, placed the local under receivership, giving district officials authority over the local's operation. Bull himself had participated in the local's fight against Morrell on the job load issue since 1949 and had grown tired of it. In the fall of 1952, Bull selected Bud Simonson as deputy administrator of Local No. 1. Simonson's presence helped to clamp down on the union's militancy. The temporary lull in labor-management conflict that ensued allowed new Morrell president McCallum and Local No. 1 to fashion a symbolic truce at a community-wide "Morrell Days" celebration in April 1954. Dissension in the local union's ranks had for the time being prompted the union to adopt a less confrontational posture. ${ }^{5}$

The conflict, however, exacerbated an already combative relationship between Local No. 1 and the UPWA international and district offices. In 1941, for example, the national Packinghouse Workers Organizing Committee (forerunner of the UPWA$\mathrm{CIO}$ ) had chastised the local for using plant bulletin boards to criticize Morrell harshly for encouraging workers not to pay their membership dues. Following World War II, the UPWA international became disgusted when Local No. 1 avoided the union's national civil rights program. Even before the receivership was implemented, local union officials felt that neither the international nor district office was willing to continue the job load fight. ${ }^{6}$

5. On the 1952-53 receivership issue, see Regular Membership Meeting minutes, 28 October and 19 November 1952, and 18 February 1953, box 11, Local P-1 Records, State Historical Society of Iowa (SHSI), Iowa City, Iowa. Jack McCoy, interview, Ottumwa, 18 May 1983, Iowa Labor History Oral Project (ILHOP), SHSI, also recounts the 1952 receivership controversy, albeit in a somewhat biased fashion since he was one of the local union leaders opposed to the walkouts and the union's militancy. The receivership appears to have been lifted by March 1953.

6. On Local No. 1's increasingly acrimonious relationship with UPWA international and district officials, see William Houston, U.S. Commissioner of Conciliation, to John Doherty, PWOC vice-chairman, 8 February 1941, folder 11, box 306; Doherty to Lewis J. Clark, PWOC District 3 director, 10 February 1941, folder 11, box 306; Packinghouse Worker, 25 September 1942; “Agreement of John Morrell and Co. and The Packinghouse Workers Organizing Committee, Locals No. 1 and 174," 3 April 1943, folder 2, box 192; Russell Bull to Ralph Helstein, UPWA president, 14 February 1949, folder 2, box 411; Edward Filliman, weekly reports, 26 March, 30 April, 7 May 1949, 2 and 30 December 1950, 6 January, 10 February, 7 July, and 17 November 1951, folder 7, box 411, and 
To be sure, many UPWA local unions' relations with the international office became strained following World War II, partly because of the union's losing battle in its 1948 nationwide strike. The UPWA had gained a 16-cents-per-hour increase following its 1946 strike, but after a long and bitter strike in 1948, the union, which had pushed for a twenty-nine-cents-per-hour increase, settled for nine cents. In Omaha, local union officials had expressed ambivalence about the need for a strike even before it began. Then once it did begin, workers attacked each other over left-wing ideological issues. Whites often blamed black workers for crossing picket lines. Omaha's packers, especially Wilson, exacerbated internal union tensions by granting replacement workers seniority (so-called "superseniority") over the UPWA strikers when they returned to work. Other UPWA cities experienced similar internal union problems. Racial antagonisms troubled Local No. 58 at the Armour plant in St. Joseph, Missouri, during the 1948 strike and long after. Whites only reluctantly worked with blacks in the union. Local No. 174 in Topeka saw about one-half of its members, most of whom were native-born whites, join a back-to-work movement during the strike, then drop their union membership immediately following its conclusion. The core Topeka unionists, consisting primarily of Volga Germans, African Americans, and Mexican Americans, only fitfully pieced their local back together. The UPWA international's civil rights program, implemented in the aftermath of the 1948 strike and aimed at overcoming some of the racial tensions that had obviously disrupted its strike effort, often further divided whites and blacks instead of creating more harmonious relations. ${ }^{\text {? }}$

folder 13, box 415; Filliman to Russell Bull, [August 1951], folder 7, box 411; Filliman, "Comments," [September 1951], folder 13, box 415; all in UPWA Records; and Virgil Bankson, interview with author, 26 September 1982.

7. For a more complete discussion of the internal union conflicts in Omaha, St. Joseph, and Topeka following the 1948 strike, see Warren, "The Limits of New Deal Social Democracy," chaps.7-9. On the 1948 strike and its aftermath in other UPWA locals, see Eric Brian Halpern, "Black and White Unite and Fight': Race and Labor in Meatpacking, 1904-1948" (Ph.D. diss., University of Pennsylvania, 1989), 526-43; and Roger Horowitz, "The Path Not Taken: A Social History of Industrial Unionism in Meatpacking, 1930-1960" (Ph.D. diss., University of Wisconsin-Madison, 1990), 546-632. 
IN OTTUMWA, internal union conflict also stemmed partly from growing discord among the rank and file. However, the sources of conflict in Ottumwa differed from the racial and ideological animosities evident in Omaha, St. Joseph, Topeka, and elsewhere. Instead, Ottumwa's friction occurred between urban and rural whites. Morrell hired rural residents to meet its expanded production needs during World War II. In 1935 none of the plant's workers lived outside the city limits. Sixteen years later, however, 27 percent did so. These rural residents were not incorporated into the thoroughly unionized culture of Ottumwa's east end, where an intersecting network of church and fraternal affiliations reinforced union loyalties. Rural employees of Morrell provided a disproportionate number of the "scabs" who disrupted the union's effort in the crucial 1948 strike. In 1951, at the height of the union's postwar production struggles with Morrell, Edward Filliman, a former local union chief steward who became a UPWA international representative in 1949, accused Morrell of hiring rural workers to break the union's solidarity. ${ }^{8}$

Another important source of internal union strife was the growing division between the union's pioneers, such as Filliman, and the men and women who came into the union's ranks during and immediately following World War II. Jack McCoy, for instance, started working full time at the plant in 1949 as a 20-year-old fresh out of military service. Admitting that he was motivated in part by dislike of hard, physical work, McCoy got involved in local union politics in 1950 and became recording secretary in 1953. In 1954 McCoy was selected as one of Local No. 1's representatives to the Ottumwa Industrial Union Council before being elected that fall to represent Wapello County in the Iowa House of Representatives. McCoy attributed the tensions between the older militants and younger members in Local No. 1 to three factors. First, McCoy cited Filliman's political ambitions, calling him a "junior size John L. [Lewis]." McCoy

8. On the impact of rural workers in the Morrell plant and its union politics, see Warren, "The Heyday of the CIO in Iowa," 375, 381-83, 385-86; and idem, "The Limits of New Deal Social Democracy," 525-30, 541-44, 557-58. For more on Edward Filliman, see Morrell Magazine, December 1948, 1. 
also resented hot-headed local stewards, some of whom he claimed led walkouts just so they could go "squirrel hunting." Finally, while many prewar union activists viewed unionism as a kind of "religion" that would reshape power relations in the plant and the local community, McCoy believed that his generation of younger workers simply wanted to work to put bread on the table for their families.

A significant subtheme of McCoy's characterization of the pro-Filliman faction was his dislike of their drinking habits. He believed that too often Filliman and his compatriots (including William Fletcher, first president of the local and the local's president again in 1952, and Harold "Cap" [or "Cappy"] Carson, a local union officer since World War II) plotted their walkouts from two beer "joints," Walker's and Champ's, located across the street from the plant. It is no coincidence that Walter Walker and Orvel Champ, whose families ran those bars, had helped to organize the CIO local at the plant and had been among its first officers. ${ }^{10}$

As later events would make more evident, however, McCoy's observation signified a deeper (and more damaging) gulf in attitudes between the remaining core of old-time, militant activists, whose attitudes about Morrell had been shaped in the preWorld War II years, and the new generation, including workers like $\mathrm{McCl}$, who had started in the plant during or immediately after the war. In particular, the older, militant unionists feared that any deviation from their hardline stance against the company would result in a return to the "old days." Years later, men in the older, militant camp - men such as Virgil Bankson, a longtime chief steward - would describe with an undertone of fear and hatred the arbitrary and calloused treatment they received before the rise of the union. In the eyes of younger workers who had not experienced the pre-union period at the

9. On the 1930s generation's sources of unionism and union ideology, see Warren, "The Limits of New Deal Social Democracy," chap. 6, esp. 328-49. On McCoy, see Regular Membership Meeting Minutes, 18 February 1953, box 11, Local P-1 Records; The Bulletin (UPWA Local No. 1's weekly newspaper), 25 January 1954, box 23, Local P-1 Records; Morrell Magazine, January 1955, 12; and Packinghouse Worker, February 1955, 11.

10. Jack McCoy, interview, Waterloo, 18 May 1983, ILHOP. 
Morrell plant, the older, more militant unionists seemed motivated more by vindictiveness and revenge against the company than by a desire for social justice. ${ }^{11}$

The generational gap overlapped with differences arising from the urban versus rural distribution of the work force. The older, more militant workers still tended to reside in the immediate plant environs of Ottumwa's east end, whereas many more recently hired employees (including younger union officials such as McCoy) lived across the river on Ottumwa's south side or outside of town. These sources of discord would continue to resonate in the union's internal politics throughout the 1950s, especially in the face of the policies that Morrell's new top official pursued.

WHEN W. W. "WALLY" MCCALLUM became president of Morrell in 1953, he was not only the first non-Morrell family member in that position in the company's long history, he was also the first top official since Morrell had arrived in Ottumwa in 1877 who did not make his home there. Consequently, workers could no longer use the comparatively extravagant local lifestyle of its top official as an emotional rallying point as they had done when the Foster family was in control. ${ }^{12}$ McCallum's

11. Local No. 32 Picnic Program, 15 August 1937, UPWA Local P-3 Records, SHSI (which includes a list of the first officers of Ottumwa Packinghouse Workers' Organizing Committee [PWOC] Local No. 32, which later became UPWA Local No. 1); and McCoy, interview. Virgil Bankson's sentiments about the pre-union era of labor-management relations can be gleaned from his ILHOP interviews, 18 October 1978 and 11 March 1983. Filliman made the reason for his militancy clear in a September 1951 report to the UPWA international office. "You may say [that continued walk-outs are] not justified, but I say the men were right. I helped break down this kind of [arbitrary work] assignment and condition years ago. [This] was one of the big deals when we organized our union[.] [T] his is a fighting deal, [as] this old company method ... was one of the things that brought on unionism. ... [We] have to fight to keep from going back to those days again. See folder 13 , box 415 , UPWA Records.

12. Thomas Dove Foster, son-in-law of the company's founder, George Morrell, established the Ottumwa plant in 1877 and was Morrell's president until his death in 1915. T. D. Foster's second son, Thomas Henry Foster, was president of the company from 1921 to 1944; the third son, George Morrell Foster, was president from 1944 to 1952; and the fourth son, John Morrell Foster, was 
lack of experience toiling with meat or handling packing workers represented another contrast with the Fosters. McCallum had been Oscar Mayer's accountant and president's assistant since 1938, but unlike the Fosters, who had always worked in the plant for at least a token stint of hands-on experience before assuming top managerial positions, McCallum's financial wizardry was his sole credential. When he met with the local union executive board and stewards soon after his ascension to Morrell's top position, McCallum "stressed the fact that he wishe[d] to see a closer harmony between the employees and the company." Nevertheless, at the supposedly conciliatory "Morrell Days" celebration in April 1954, he made an implicit (and threatening) connection between Morrell's finances and its workers' militancy. "The Ottumwa plant," he said, "is, in a sense, at a standstill. We are killing hogs and cattle, processing and selling good meat products, paying wages and so forth - but the plant is losing money - and has been losing consistently over the last six years," that is, since the 1948 strike and its subsequent repercussions in labor-management relations. ${ }^{13}$

McCallum's "solution" for company losses was threefold: he began buying plants around the country, moved the company's general headquarters from Ottumwa to Chicago in December 1955, and continued to contest the union's power to influence production decisions. The first two decisions stemmed

president from 1952 to 1953 . W. H. T. Foster, T. D.'s oldest son, managed the Sioux Falls Morrell plant from 1913 to 1939. T. D., T. H., G. M., and J. M. Foster all lived in Ottumwa. The Fosters were the preeminent family of wealth, power, and fashion in Ottumwa for the first half of the twentieth century. Lawrence Oakley Cheever, The House of Morrell (Cedar Rapids, 1948); and R. Ames Montgomery, Thomas D. Foster: A Biography (Cedar Rapids, 1930), convey some of the Foster family's history.

13. On the significance of Morrell/Foster family members living in Ottumwa for increasing worker resentment, see Warren, "The Limits of New Deal Social Democracy," 318-19; and Warren, "The Heyday of the CIO," 367. In his ILHOP interview, Jack McCoy recalled the Foster family's ostentatious displays of wealth and their "down the nose attitude" toward the people of Ottumwa. Segments of this part of the interview are quoted in Shelton Stromquist, Solidarity and Survival: An Oral History of Iowa Labor in the Twentieth Century (Iowa City, 1993), 54-55. On McCallum, see Morrell Magazine, January 1954, 3; April 1954, 5; December 1958, 7; and The Bulletin, February 1954. 
from McCallum's desire to follow the traditional financial path of the Big Four meatpacking plants: establish a high-volume sales empire of plants, all controlled from America's central packing hub, Chicago. Swift, Armour, Cudahy, and Wilson had traditionally garnered sizable profits, in an industry typified by very slim profit ratios, by slaughtering and processing meat at as many plants as possible. In hopes of mimicking their success, Morrell purchased thirteen small plants throughout the Midwest and South between August 1954 and February 1963. Most were nonunion and paid relatively low wages, but they did boost Morrell's total sales from just over $\$ 300$ million in 1954 to $\$ 554$ million in 1961. During the same period, Morrell also acquired financial interests in Foxbilt, a livestock feed and hybrid corn producer, and Golden Sun Mill, another livestock feed manufacturer. ${ }^{14}$

McCallum's decision to pursue such a strategy would prove to be antiquated, however, once Iowa Beef Processors' revolutionary combination of more isolated, rural slaughtering facilities, nonunion work forces, and streamlined, on-rail, boxed-beef technology rapidly transformed meatpacking (and its profit margins) beginning in 1961. When Currier Holman and Andy Anderson started their Denison, Iowa, plant, meatpacking was still largely typified by urban midwestern locations where animals were shipped on the "hoof," although the transition from urban to rural locations to decrease shipping costs had been occurring gradually since the end of World War I. IBP's real innovations were in the introduction of highly automated assembly line production techniques in combination with the development of "boxed" beef. Various firms had introduced automated techniques piecemeal in the 1950s but not in the integrated way that IBP did. Boxed beef referred to the cutting of beef carcass quarters into marketable cuts at the plant instead of having retail butchers handle this step as had been the traditional practice. Most of the old-line plants were unionized

14. On McCallum's financial strategy for Morrell, see National Provisioner, 21 August 1954, 25; Morrell Magazine, September 1954, 3; July 1955, 6; January 1956, 10; February 1956, 11; June 1956, 3; October 1959, 2; January 1960, 2; May 1960, 2; January 1962, 2; June 1962, 4; January-February 1963, 2; JanuaryFebruary 1964, 3; and May-June 1964, 15. 
as well, whereas, partly because IBP's technical processes did not require skilled labor, they could hire unskilled, nonunionized workers. Much to the surprise of Morrell and other traditional packers, IBP's integrated production practices soon left them scrambling to innovate or be eliminated as competitors. ${ }^{15}$

Besides choosing outdated financial and production strategies, McCallum exacerbated volatile employee relations at the plant by selecting Harry E. Hansel Jr. to help manage the confrontational industrial relations department that Charles "Mad Dog" Campbell had administered from 1947 to 1952. "Kid" Hansel, as the old-time unionists derisively called him, had started working at the Ottumwa plant in 1940. In 1942 he was transferred to the new industrial engineering department. Over the next decade, he helped to establish time studies and gain time to challenge Local No. 1's power to control production decisions. Gain time, in particular, became an effective weapon that management wielded to deflect workers' allegiances away from Local No. 1. Essentially, gain time was a variation on the old Frederick Winslow Taylor notion of incentive pay (or piecework) that allowed employees to work shorter hours for the same pay as long as they met the production standard for the job. In effect, workers who participated in gain time practiced a self-induced job speedup. Through 1960, when he was transferred away from Ottumwa, Hansel, as operations manager and assistant manager of a revamped industrial relations depart-

15. Sources describing the traditional financial strategies of the Big Four packers include Richard J. Arnould, "Changing Patterns of Concentration in American Meat Packing, 1880-1963," Business History Review 45 (1971), 18-34; Jimmy M. Skaggs, Prime Cut: Livestock Raising and Meatpacking in the United States, 1607-1983 (College Station, TX, 1986); Mary Yeager, Competition and Regulation: The Development of Oligopoly in the Meat Packing Industry (Greenwich, CT, 1981); and Warren, "The Limits of New Deal Social Democracy," 41-55, 66-72. IBP awaits its historian, but crucial historical information is available in a series of articles Dale Kasler wrote for the Des Moines Register, 18-25 September 1988. Many management employees of Morrell communicated their criticisms of McCallum's financial strategy to me over the years. Lawrence Reedquist, a traffic engineer at Morrell for nearly fifty years, described McCallum's objective of buying old plants instead of constructing new ones as pushing Morrell's fortunes from "bad to worse" during the 1950s and 1960s. Reedquist, interview with author, 11 August 1981 (notes in author's possession). 
ment, wholeheartedly protected the practice of gain time and gain timers themselves. ${ }^{16}$

McCallum and Hansel's continued assaults on the local union's power to affect workplace decisions resulted in a resurgence of union aggressiveness beginning in 1955. "Cap" Carson, Local No. 1 president in 1955 and 1956, led a new charge by the old-time militant faction of the work force against management's directives. In The Bulletin, the union's newspaper, leadership waged a propaganda battle, as fierce as the one it had conducted in 1949-1952, against Morrell and its policies. The paper attacked "Kid" Hansel in particular, accusing him of undermining the union contract, including seniority provisions. ${ }^{17}$

During the first half of 1956, virtually the same group of older, militant officers from 1955 continued to press Morrell on gain time. Union officials recalled the period from 1949 to 1952, when workers had been fired for failing to meet new production standards. They urged the rank and file to resist gain time incentives, because new standards could result in further job losses and consequent loss of union power. As evidence, Local No. 1 officials pointed to Morrell's shutdown of the dog food manufacturing department in December 1955 based on time study conclusions. The department was small, but they believed the same thing would happen soon all over the plant. ${ }^{18}$

Officials also noted the deceit of the company slogan adopted at the 1954 "Morrell Days" celebration - "Morrell Needs You and You Need Morrells" - in light of the new company policy of discharging employees or delaying sick pay for absenteeism

16. For details about Hansel's career, see Morrell Magazine, March 1944, 8; August 1955, 6; October 1956, 8; and September 1962, 3. Harry Braverman's Labor and Monopoly Capital: The Degradation of Work in the Twentieth Century (New York, 1974) contains one of the most fully developed treatments of Frederick Taylor's concept of piecework and incentive pay. See also Stromquist, Solidarity and Survival, 191-99, for a more complete discussion of the widespread use of incentives and gain time in Iowa factories after World War II.

17. The Bulletin, 31 January, 23 March, and 2 May 1955. Although not indicative of the internal divisions affecting local union politics, Jack McCoy's election to the state legislature on the Democratic ticket in November 1954 did indicate labor's remaining powerful local presence in Ottumwa and Wapello County. See Packinghouse Worker, February 1955, 11.

18. The Bulletin, 9 and 25 January and 5 March 1956. 
and tardiness. In fact, union leaders claimed that tactic was simply another union-busting technique. They felt Morrell's underlying attitude was "LET'S BREAK THIS DAMN UNION AND RUN THE COMPANY THE WAY WE SEE FIT."19

AFTER MANY OF LOCAL NO. 1's newer members complained that union militancy was spiraling out of control, Russell Bull again placed the union in receivership. Unlike the case in 1952, however, Bull placed a prominent member of the new generation of workers at Morrell, Dave Hart, in charge as deputy administrator. Although all of the 1956 officers were retained for the remainder of the year, The Bulletin's rhetoric became much less antagonistic toward Morrell. Then, in the local's 1957 elections, most of the older militants lost to members of the new generation. Five of the nine local officers were new in 1957, with the two key changes occurring in the positions of president and chief steward. In runoff elections Tom Cohagan defeated "Cap" Carson for local union president and Louis Crumes defeated Art Johnson for chief steward. In contrast to the new generation of officials, Johnson, like Carson, was a longtime Morrell employee. Born in Blekinge, Sweden in 1903, he started at Morrell in 1922 and worked in the mechanical department. Crumes had served as Local No. 1's vice-president in 1953, when, under UPWA District No. 3 receivership, Dave Hart had served as chief steward, Lester Bishop had been president, and Bob McIntosh had been secretary-treasurer. McIntosh was then elected to the same union office in 1957. Just one of the nine 1957 officers lived in the east end packing district neighborhood, whereas both "Cap" Carson and Art Johnson did. ${ }^{20}$

Local No. 1's new president, Tom Cohagan, was a prominent member of the new generation of Morrell workers who,

19. Ibid., 24 May 1956 (the quotation was in all caps in the source.)

20. Local No. 1 Special Executive Board Meeting, 8 June 1956, box 11, Local P-1 Records; The Bulletin, 28 January 1957; 3 February 1953 membership meeting, box 11, Local P-1 Records; Arthur G. Johnson obituary (died 14 January 1991), Ottumwa Courier, Morrell-Ottumwa workers obituary file, in author's possession; and Polk's Ottumwa City Directory, 1957. In his ILHOP interview, Jack McCoy characterized both Dave Hart and Lester Bishop as leaders of the "new" generation of anti-Filliman local union officials. 
like Jack McCoy, wanted more stable relations with management. Born in Knoxville, Iowa, and educated in Des Moines, Cohagan had not been part of the union-building struggles at Morrell in Ottumwa during the 1930s. First employed at Morrell in 1939, Cohagan was in military service for a good part of the World War II period. Like Jack McCoy, he became active in local union politics when he returned to the plant. His opposition to Filliman first became evident in 1951. Filliman, in one of his weekly UPWA field representative reports, noted that Cohagan, as Local No. 1 recording secretary, had been corresponding with Lewis Clark, a prominent UPWA international officer (as well as a vocal anticommunist) about the current chaos in the Ottumwa plant. Filliman noted with disgust that Cohagan's views were "purely personal" and did not represent the views of all local unionists (including, of course, Filliman's). Cohagan's clandestine correspondence with Clark seems to have kept him out of local union offices for the next several years, even during 1953, when many other newer and less combative workers first had an opportunity to hold office. ${ }^{21}$

Not surprisingly, Local No. 1's new officers in 1957 immediately toned down much of the militant rhetoric of The Bulletin. For instance, the February 18 issue asked union members to follow the correct sick pay procedures. The spirit of the brief article was that the local union needed to comply more cooperatively with the general provisions of its contract with Morrell. Nevertheless, regarding gain time, the new leadership continued the older, more militant leaders' viewpoint. A May 6 article in

21. Tom Cohagan obituary (died 3 May 1989), Ottumwa Courier, MorrellOttumwa obituary file; Edward Filliman, UPWA field representative weekly report, 23 June 1951, folder 13, box 415, UPWA Records. For more on Lewis Clark's anticommunism and his role in the internal politics of the UPWA international, see Regular Membership Meeting, 6 January 1937, Midwest Union of All Packinghouse Workers, 1936-37 Minute Book, Local No. 3 Records, SHSI; Virgil Bankson, interview with author, 26 September 1982; Don Harris, interview, 8 June 1978, ILHOP; Herbert March, interview, 21 October 1986, United Packinghouse Workers of America Oral History Project (UPWAOHP); Norman Dolnick, interview, 1 October 1985, UPWAOHP; Ed Roche to Herbert March, 11 September 1945, folder 1, box 308, UPWA Records; Clark to March, 7 November 1945, ibid.; Philip Weightman to March, 10 April 1946, ibid.; March to Weightman, 18 April 1946, ibid.; Clark to March, 29 April 1946, ibid.; March to Clark, 8 May 1946, ibid. 
The Bulletin asked the rank and file not to use the incentive system since "greed cuts [your] brothers throat" and denies work to everyone. 22

By May 1957, the older militants in Local No. 1 attempted to regain power. At the union's regular membership meeting on May 14, a motion by John Bedner, vice-president of the local in 1955 and a member of the local's bargaining board in 1956, seconded by Art Johnson, proposed to lift the local's receivership. The motion carried. A similar proposal carried at a special executive board meeting of the local two days later. Over the next couple of weeks, however, as the UPWA district office stalled on the local's request, the older militants heard rumors that Tom Cohagan, on orders from Dave Hart, was planning to print a detailed plea for retaining the local's receivership. Sure enough, this plea, printed in the June 3 issue of The Bulletin, noted that the "old union leaders, many of whom were recently defeated," wanted to lift the administratorship, without which, from Cohagan's point of view, the local would return to the "old days when 87 [sic] work stoppages took place." ${ }^{23}$

With UPWA District No. 3 Director Russell Bull himself in attendance, the union's vote that night demonstrated the ascendancy of the new generation's views among the rank and file. Their support for retaining the receivership carried by a landslide vote of 482 to 170 . Art Johnson asked that the secret vote be made standing, so each person's position on the internal union struggle would be evident to all, but Russell Bull intervened and "demanded a secret ballot." Bull's position helped restrain what might have become an exacerbated internal union fight, but it also suggests that UPWA District No. 3 as well as the UPWA international were increasingly interested in promoting local union malleability. ${ }^{24}$

22. The Bulletin, 18 February and 6 May 1957.

23. Regular Membership Meeting, 14 May 1957; Special Executive Board Meeting, 16 May and 1 June 1957; and The Bulletin, 3 June 1957.

24 . Given declining rank-and-file participation in virtually all union activities in the $1950 \mathrm{~s}$, the 23 percent turnout for the vote (652 total ballots cast out of about 2,800 members) on receivership indicates a fairly high level of interest in union affairs at the Ottumwa plant. See Special Membership Meeting Minutes, 3 June 1957, box 11, Local P-1 Records, SHSI. For Local No. 1 member- 
Over the next several years, members of Morrell's new generation gradually solidified their dominance in Local No. 1. After another narrow runoff victory over "Cap" Carson in 1958, Tom Cohagan remained local president until 1963. By 1962, the only members among the nine top officials with ties to the older militants were Virgil Bankson, chief steward, and John Bednar, bargaining board member. Although The Bulletin became less combative, especially in regard to production decisions, it nonetheless retained a concern about the corrosive effects of gain time. One general reprimand of gain timers suggested that workers used their free time for sexual encounters in the parking lots. The article claimed that news of the this abuse "could break up many marriages if all the facts were exposed." Hansel was also regularly chided for protecting gain timers even at the risk of sparking "open war with the Union." ${ }^{25}$

LOCAL NO. 1's declining militancy dovetailed with changes in the structure of the work force, many of which were related to shifts in workers' residential patterns. Morrell's demolition and burning of many remaining, though largely vacant, houses in the near east end during the summer of 1962 epitomized the end of the historic connection between Morrell's militant union tradition and residence in the plant's environs. Morrell proudly described its destruction of the remaining houses next to the plant in an article titled "Urban Renewal" in the company magazine. In 1935, 39 percent of Morrell's workers had lived in the east end. By 1957, only 22 percent did, and by 1965 just 15 percent would live there. On the other hand, the proportion of Morrell employees who lived outside the city limits went from zero in 1935 to 33 percent in 1965. To be sure, by 1962 much of the older tension between the east enders and the out-

ship figures from 1952 to 1960 , see folder 7, box 492, UPWA Records. On the UPWA's increasing concern in the 1950s for local union tractability, see Warren, "The Limits of New Deal Social Democracy," chap. 10.

25. The Bulletin, 30 September and 14 October 1957, 29 January and 22 December 1958, 30 January 1961, and 19 January 1962. An interesting illustration of the changing concerns of Local No. 1's membership was the formation of the Iowa Avenue Club in May 1957 for workers interested in stock market investments. See Morrell Magazine, March 1960, 3. 
of-towners was gone largely because the local union itself no longer contested company production decisions. Yet local union leaders' irritation about the importation of workers from outside Ottumwa was still evident enough in 1962 when The Bulletin noted that McCallum had been quoted as saying "out of towners are more efficient than Ottumwa people if they were hired in the last nine years" (that is, since the beginning of his tenure as president). Company officials lauded the progress they saw in replacing old east end homes with parking lots, a project made both possible and necessary because of the transition in employees' places of residence. After the demolition and burning, Morrell officials claimed that more than ten acres of parking were available to plant employees! ${ }^{26}$

The number of people employed in the Ottumwa plant had been affected by Morrell's use of new technologies in combination with gain time since the early post-World War II years. Yet wholesale job losses at the Ottumwa plant did not cause widespread tension among workers until the early 1960s. Although 39,100 jobs were eliminated in meatpacking throughout the United States between 1956 and 1961, union membership at Morrell remained constant through most of the 1950s. As the pace of technological innovation picked up in the early 1960s, however, there were job losses at Morrell as well as at many other "old-line" meatpackers. Paul Bissell, beef department superintendent beginning in 1956 after working his way up through the ranks in the beef kill starting in 1930, recalled that new technologies transformed Ottumwa's beef killing process only after 1961. Until that date, "as far as beef operations were concerned, little had changed back to the '30s."

26. Morrell Magazine, August 1962, 7; and The Bulletin, 17 December 1962. My calculations of workers' residences are based on systematic samples of the 1935 McCoy's Ottumwa City Directory, 1957 Polk's Ottumwa City Directory, and 1965 Polk's Ottumwa City Directory. I am defining the east end as corresponding to precincts one and two as described in Ordinance No. 1313 of the 1934 revision of Ottumwa's Municipal Code.

27. On the combination of technology and gain time used by Morrell to shut down many departments, see Ethel Jerred, interview, Ottumwa, 5 October 1981, ILHOP. Between 1952 and 1957, Local No. 1's total membership ranged between 2,700 and 2,950. It then fell to 2,400 in 1958 before recovering a bit to just over 2,500 in 1960. See folder 7, box 497, UPWA Records. I interviewed 
Although The Bulletin emphasized losses in traditionally male-dominated departments such as the beef kill, some of the hardest hit departments, such as sliced bacon, had been predominately female. Unfortunately for those women, Local No. 1, like most UPWA locals, had adopted a system of departmental, as opposed to plantwide, seniority in order to prevent management's arbitrary transfer of workers, particularly union activists, from department to department. Because most packing departments were sex-segregated, this meant that women had little opportunity to "bump" into male-dominated departments when technological innovations eliminated many women's jobs. ${ }^{28}$

By 1964-65, more layoffs and continued pressure from longtime women employees presented Local No. 1's leadership with a dilemma. How could they help women union members without alienating male workers, especially when men had long dominated the plant's work force and were its most ardent union activists? In 1935, women constituted just 9 percent of Morrell's work force compared to 15 percent in 1951 and 14 percent in 1957. Only one woman (Mary Shoemaker from the sausage department) had ever been elected an official of Local No. 1. Moreover, most of the local's union leaders were admittedly sexist. Jesse Merrill, a hog kill worker and president of Local No. 1 from 1967 until the plant closed in 1973, claimed he had long believed that "if the man's head of the house he should have the job." Virgil Bankson, Local No. 1's chief steward during the 1960s, was even more adamantly

Paul Bissell on 10 January 1983 (notes in my possession). On the restructuring and job cuts in meatpacking, see Fehn, "Chickens Come Home to Roost": Industrial Reorganization, Seniority, and Gender Conflict in the United Packinghouse Workers of America, 1956-1966," Labor History 34 (1993), 333, 341. The Bulletin described job losses due to technological and time study changes in its issues of 11 and 25 March 1963, and 30 March 1964. See also "Facts and Figures," vol. 14, no. 21, 27 July 1961, folder 14, box 513, UPWA Records.

28. For analyses of the impact of technological innovations in the meatpacking industry on women's employment and concerns, see Bruce Fehn, "Striking Women: Gender, Race, and Class in the United Packinghouse Workers of America (UPWA), 1938-1968" (Ph.D. diss., University of Wisconsin-Madison, 1991), chap. 6; and idem, "Chickens Come Home to Roost," 324-41. 
against giving "men's jobs" to women. He claimed "there's more divorces over women taking men's jobs than anything else." In the face of such attitudes, women started attending local union meetings en masse in 1964-65 to protest the union's continuing commitment to departmental seniority, but they made little headway with union leaders. ${ }^{29}$

After getting nowhere with the local, thirty women contacted the Equal Employment Opportunity Commission in Washington, D.C. The Washington office told them to approach David Dutton, a Waterloo attorney and civil rights activist. Dutton then contacted the UPWA international, threatening a lawsuit on the women's behalf if Local No. 1 did not follow the guidelines established by the 1964 Civil Rights Act's Title VII prohibiting sex discrimination. UPWA international officials promptly pressured Local No. 1 to adopt the so-called ABC seniority plan. " $A$ " jobs were the most physically demanding and thus of interest mostly to men. " $B$ " jobs - light work in relatively clean conditions - were reserved for women. " $\mathrm{C}$ " jobs were open to both men and women. When the new seniority system was finally put into place in March 1966, however, Ottumwa's male workers either refused to cooperate with it or conspired to undermine women's efforts to tackle " $C$ " jobs. After two weeks, many women concluded that union officials were hindering the implementation of the new plan. In April

29. For comparative statistics on the percentages of men and women workers in midwestern meatpacking, see Warren, "The Limits of New Deal Social Democracy," Appendix B. Dennis A. Deslippe, "We Had an Awful Time with Our Women': Iowa's United Packinghouse Workers of America, 1945-1975," Journal of Women's History 5 (1993), 13-14, notes that before passage of Title VII of the Civil Rights Act, women made up just 13 percent of the membership in UPWA District 3 as opposed to 21 percent throughout the entire union. Ottumwa was even more thoroughly a bastion of male packing workers than many other midwestern plants. In 1950, for instance, the Rath plant in Waterloo employed 23 percent female workers and Armour in Mason City employed 26 percent. The Ottumwa statistics come from Ottumwa city directories for 1935,1951 , and 1957. My information on Mary Shoemaker comes from her obituary (Ottumwa Courier, 18 February 1991). For the sexism issue, see Jesse Merrill, interview, Ottumwa, 16 September 1981, ILHOP; and Virgil Bankson, ILHOP interview, quoted in Stromquist, Solidarity and Survival, 231. For more on the women's struggles at the Ottumwa plant, see Fehn, "Chickens Come Home to Roost," 335-39; and idem, "Striking Women," 276-87. 
1966 twenty-one women asked Dutton to move ahead with a formal lawsuit under the Civil Rights Act's Title VII. ${ }^{30}$

Less obvious to many outsiders and subsequent observers of the battle of sexes at the Morrell plant was the local union's concern that management, especially the union's old nemesis Harry Hansel, hoped to use this issue to splinter the union. After a two-year stint from 1960 to 1962 as manager of Morrell's plant in Philadelphia, Hansel moved to the main offices in Chicago as a member of the corporate personnel and public relations department. In 1965-66, when the ABC plan was debated and the women's grievances were aired, Morrell sent Hansel to negotiate with Local No. 1 officials. Ethel Jerred, chief steward in the sliced bacon department, later recalled that "Harry Hansel tried to help [the women]," but union officials, especially Merrill and Bankson, blocked his efforts. Yet Jerred also revealed the company's lackluster commitment to the women's efforts by noting that "the company would prefer to hire new people from outside town rather than move women with as much as twenty-eight years seniority" into open jobs. ${ }^{31}$

Historian Dennis Deslippe has further contended that UPWA international officers were sexist in defending the ABC seniority plan. In Deslippe's view, UPWA President Ralph Helstein "still embraced . . p protective labor laws for women," since Helstein argued that women could not handle the physical aspects of many packing jobs. The Federal District Court in Des Moines effectively sidestepped the discrimination debate when it threw out the women's case on a technicality. The court then gave Morrell time to reach a settlement with the women. On July 12, 1968, the court found Morrell in compliance with Title VII, and Morrell settled with each of the twenty-one women for $\$ 450 .^{32}$

30. Fehn, "'Chickens Come Home to Roost," 334, 337-39; Deslippe, "'We Had an Awful Time with Our Women," 17-21; Jerred, ILHOP interview; and David J. Dutton to President, Local No. 1, UPWA-CIO, 18 April 1966, folder 8, box 25, Local P-1 Records. Stromquist's Solidarity and Survival, 224-33, provides additional discussion of the women's battle at the Ottumwa plant.

31. Morrell Magazine, September 1962, 3; and Jerred, ILHOP interview.

32. Deslippe, "We Had an Awful Time with Our Women," 20-22. 
DESPITE ONGOING HARASSMENT from men, women activists in Local No. 1 continued to push for greater access to more jobs. They had some success. By the late 1960s, however, the women's employment issue had become submerged in more dramatic discussions about the plant's likely closing. Although McCallum's 1954 "Morrell Days" speech had established an ominous tone about the company's future in Ottumwa, rumblings among workers about the plant's possible closing did not begin to reverberate seriously until the early 1960s. Morrell's first threat to close the Ottumwa plant if the union did not back off on some of its demands came during the 1961 contract negotiations. The 1964 contract negotiations included similar threats. For the first time, union leaders also openly criticized McCallum's financial strategy.

Who do you think you are kidding by buying all of these small plants and hiring these people for wages that are ridiculous. Not too long ago in a meeting with Harry Hansel, a statement was made to the Bargaining Board, [sic] the Company was making arrangements to transfer the work out of the Ottumwa Plant and distribute it to other Plants. I might say this is already been [sic] done in some instances.

Still, very few workers felt that the company would actually close the plant. Many employees would later recall that threats to close the plant abounded throughout the company's last twenty years in Ottumwa, especially around contract time. For workers hired after the early 1950s, warnings about the possibility of a closing were standard background noise. ${ }^{33}$

All this changed in 1967, when AMK, formerly American Seal-Kap, purchased Morrell in what Fortune termed the "financial coup of 1967." As part of the largest "merger mania" in American history since 1900 (before the even bigger "merger mania" period that began at the end of the 1970s), the late 1960s saw Ling-Temco-Vought (LTV) acquire Wilson; Greyhound buy out Armour; and Swift become the conglomerate Esmark by

33. Ibid., 22-23; The Bulletin, 17 September 1961 and 21 September 1964; and Merrill, ILHOP interview. Comments about the constant threat of closing by the early 1960s are a steady refrain in most of the interviews I have conducted with Morrell workers as well as in the Morrell survey questions I distributed among Morrell retirees at their annual plant closing reunion in 1982. 
buying Vickers Petroleum, Playtex, and STP in the 1960s and '70s. AMK took over Morrell by buying 33 percent of its overvalued stock. Eli Black, president of AMK, later claimed, "we bought a dollar for 25 cents." Consequently, AMK, originally a producer of milk bottle caps with sales of $\$ 40$ million in 1967 , took over a company with $\$ 800$ million in sales. ${ }^{34}$

Although McCallum's purchase of numerous small packing plants and relocation of Morrell's headquarters from Ottumwa to Chicago may have diverted much needed funds away from modernizing the Ottumwa plant, at least while Morrell remained independent it had not taken active steps to close the Ottumwa plant. AMK had no such qualms, though. AMK VicePresident Morton H. Broffman explained the company's policies in regard to Morrell as "tough-minded management action." President Eli Black criticized McCallum for his outdated production planning methods and for using each of Morrell's plants as "individual profit centers" with "no central plant control."

AMK's message to the Ottumwa plant was modernize or else, and the rank and file felt compelled to respond cooperatively: Local union leaders initially balked when Harry Hansel came to Ottumwa in the fall of 1969 and announced that Morrell would spend $\$ 6.5$ million to modernize the plant if the union would freeze its severance pay. After some debate, however, the union finally agreed. Further dramatizing how far it had strayed from its militant traditions, the leaders of Local P-1

34. The best source on the "merger mania" in meatpacking at the end of the 1960s is Harold B. Meyers, "For the Old Meatpackers, Things are Tough All Over," Fortune (February 1969), 90, 134. Bennett Harrison and Barry Bluestone's The Great U-Turn: Corporate Restructuring and the Polarizing of America (New York, 1988), chap. 3, is a good source on the 1960s restructuring mania. AMK scored an even bigger financial coup in 1968 when it purchased the giant United Fruit Company. Eli Black and United Brand-AMK's new name after its purchase of United Fruit - quickly fell on hard times not long after 1968. In 1975, Black committed suicide by leaping from his New York City skyscraper office, apparently because of the impending scandal over his $\$ 1.25$ million payment to a Honduras head of state's Swiss bank account in exchange for a banana export tax reduction of 75 cents per box. Two weeks after news of the scandal was released, the Honduras government toppled and United Brand's stock fell to an all-time low. See Everybody's Business: An Irreverent Guide to Corporate America (San Francisco, 1980), 78-79.

35. Meyers, "For the Old Meatpackers, Things are Tough All Over," 90, 134. 
(as the local was renamed after the 1968 merger of the UPWA into the AMCBW) agreed for the first time in its history to train their own people in time study methods so they could abide by Morrell's modernization (and layoff) plans. In contrast, Jack Moses, a veteran industrial engineer at the plant, later noted that the chief steward at Morrell's plant in Sioux Falls, South Dakota, a longtime AMCBW stronghold, had always been trained in time studies methods. "He even checked his own men with a stopwatch." During late 1970 and 1971, the Ottumwa local also agreed to company plans for wholesale layoffs in the sliced bacon, canning, beef, and pork divisions. About six hundred people were laid off in the pork division alone in $1971 .^{36}$

By early 1973, however, word was out that the Ottumwa plant would close in July. Jesse Merrill and Harold Trimble, chief steward in 1973, conveyed their utter frustration with Morrell and its new president, Elias Paul, in a frank letter to Patrick Gorman, secretary-treasurer of the AMCBW.

In 1970, we thought, the Company was sincere in trying to make the plant go, so we conceded to freeze our severance pay rate and credited service at the 1970 level, only to find out their intentions weren't honorable. We gave them 11 percent more kill, cutting of hogs [that is, a faster pace in the kill and cut departments], beef with modernization, and lost people besides. God knows we tried and we find him [Paul] crying on your shoulder for more concessions. ... If people like him make it to heaven, than [sic] we know there is no one in hell and it is a myth.

Gorman responded in patronizing fashion. Paul "was not crying on my shoulder," he replied; he seemed sincerely saddened by the imminent closing. Gorman suggested, moreover, that Merrill and Trimble should be ashamed for writing him in a way that suggested that they did not "care a hoot whether the plant closes or not." Paul's letter to Gorman was even more revealing. Although Paul noted in passing his "concern about the impact on the employees at Ottumwa and the impact on the town of

36. The Bulletin, 24 February, 23 and 30 November 1970, 8 February and 9 April 1971; Jack Moses, interview with author, 12 September 1982 (notes in author's possession); and Merrill, ILHOP interview. 
Ottumwa" if the plant closed, he went on to excuse Morrell of ultimate responsibility for its demise.

John Morrell and Co. has been taking money from other locations for most of these past twenty-five years and putting it into Ottumwa in an attempt to turn the [plant's losses] around. There is little point in pursuing the wisdom of this past action at this later date, but I believe we all would agree the company has tried hard to solve a difficult problem. I'm sure that the company's patience with this trying situation has always been tempered by the effects that any drastic action would have had on the welfare of the community and on the individual employees involved. ${ }^{37}$

One is left to wonder about the precise meaning of Paul's statement about the "company's patience with this trying situation." Yet it seems likely that in part he was castigating Ottumwa's militant union tradition.

TO THIS DAY, veterans of Ottumwa's long post-World War II labor-management struggles continue to debate the real reasons for the plant's closing. Many management and union leaders agree that by the 1960 s the Ottumwa plant was clearly outdated in terms of design efficiency. Lawrence Reedquist, a longtime traffic engineer, emphasized the irony that Morrell had built the plant to last "one hundred years" without knowing that by the 1960s new-line packing companies such as Iowa Beef Processors were building plants to last "no more than 40 years." Although it was equipped with the most up-to-date system of elevators and internal conveyance systems, the Ottumwa plant by the 1960 s consisted of dozens of separate, multistory buildings that defied modern processes of packing disassembly. Many workers had to be employed simply to truck products between the various buildings. Still, Jack Moses, another longtime Morrell supervisor, pointed to Morrell's continued operation of its (now seriously downsized) packing plant in Sioux Falls. There, with buildings nearly as old as the Ottumwa facility, Morrell continues to turn out millions of dollars worth of meat products. As Mickey Lauria and Peter S. Fisher point

37. Merrill and Trimble to Gorman, 6 May 1973; Gorman to Merrill and Trimble, 11 May 1973; Paul to Gorman, 24 April 1973, box 11, Local P-1 Records. 
out in their study of plant closings in Iowa, "any given plant cannot be said to be obsolete in any absolute sense; it could be made efficient at some cost." Moses, as well as many former Ottumwa workers, believed Morrell kept the Sioux Falls plant open because its AMCBW-affiliated work force had long been more cooperative on production issues. ${ }^{38}$

An examination of the specific causes of the Ottumwa plant's ultimate demise would be fodder for another study. Nevertheless, it appears plausible that the erosion of workers' militancy allowed Morrell to decide the fate of the plant without much opposition. Local P-1's internal divisions and the complacency this created meant that workers were unable to apply much pressure on Morrell or city authorities to do much to keep the plant open. In 1969 Local P-1 and other Ottumwa union members formed the Greater Ottumwa Labor Development (GOLD) Corporation to push for greater involvement by labor in Morrell's future as well as in the city's post-Morrell plans. Yet by 1972 GOLD members complained that their occasional requests for information and input had usually been ignored by city and corporate authorities. Ottumwa's predicament contrasted noticeably with Waterloo's case in the late 1970s. There, public officials and local union members worked diligently to keep the Rath packing plant open. ${ }^{39}$

Local P-1's internal discord generated considerable bitterness among workers once the plant closed. Just as many former management personnel claimed, some of those who joined the union in the post-World War II years, such as Jack McCoy and Jesse Merrill, blamed the militant unionists for the plant's fate.

38. Reedquist, interview with author; Moses, interview with author; and Mickey Lauria and Peter S. Fisher, Plant Closings in Iowa: Causes, Consequences, and Legislative Options (Iowa City, 1983), 52. Chap. 5, pp. 41-64, of Lauria and Fisher's study deals specifically with the meatpacking industry. Among the 1982 Morrell surveys I collected, Elizabeth J. "Sue" Smith gave credence to the Sioux Falls "theory" by noting how she had been told that Morrell closed the wrong plant.

39. GOLD's Newsletter (Greater Ottumwa Labor Development Corporation), c. March 1972, box 11, Local P-1 Records; Gene Redmon, Chuck Mueller, and Gene Daniels, "A Lost Dream: Worker Control at Rath Packing," Labor Research Review, 5-23; John Portz, "An 'Offset' Response: Waterloo, Iowa, and the Rath Packing Company," in The Politics of Plant Closings (Lawrence, KS, 1990), 54-84. 
While appreciative of the role the local's militancy had played in establishing significant gains for its members, McCoy and Merrill felt that the militants' quest for their own sense of justice and fairness had jeopardized the long-term viability of the plant. These declarations of blame can be dismissed as overly simplistic, but they do confirm the importance of internal divisions in the experience of Morrell-Ottumwa workers after the early 1950s. Cultural homogeneity and a common sense of community experience had given the early local union much of its strength. That underpinning eroded in the face of Morrell's continued onslaught on workers' power within the plant, the company's recruitment of rural workers who were primarily concerned with putting bread on the table rather than battling an unjust company, and struggles between men and women over declining job opportunities in the face of massive changes in the industry. As a result, Morrell-Ottumwa's workers lost not only their militant union but their jobs as well. 
Copyright of Annals of Iowa is the property of State of Iowa, by \& through the State Historical Society of Iowa and its content may not be copied or emailed to multiple sites or posted to a listserv without the copyright holder's express written permission. However, users may print, download, or email articles for individual use. 